\title{
Effect of epithelial growth factor on matrix metalloproteinase-2 and E-cadherin/ $\beta$-catenin expression in an in situ model of tumorigenesis
}

\author{
NATALIA FESTUGATTO NAVARINI ${ }^{1}$, VERA CAVALCANTI DE ARAÚJO ${ }^{1}$, MARCELO SPERANDIO ${ }^{1}$, \\ MARCELO HENRIQUE NAPIMOGA ${ }^{2}$, LUCAS NOVAES TEIXEIRA ${ }^{1}$, \\ NEY SOARES DE ARAÚJO ${ }^{1}$ and ELIZABETH FERREIRA MARTINEZ ${ }^{1}$
}

\author{
${ }^{1}$ Department of Oral Pathology and ${ }^{2}$ Laboratory of Immunology and Molecular Biology, São Leopoldo Mandic Institute \\ and Research Center, Campinas, São Paulo 13045-755, Brazil
}

Received February 28, 2017; Accepted May 18, 2017

DOI: $10.3892 / \mathrm{ol} .2017 .6513$

\begin{abstract}
The aim of the present study was to analyze the in vitro effect of various doses of epidermal growth factor (EGF; 5 and $10 \mathrm{ng} / \mathrm{ml}$ ) on matrix metalloproteinase-2 (MMP-2) secretion and E-cadherin/ $\beta$-catenin expression by co-cultured cells that mimic an in situ carcinoma ex-pleomorphic adenoma, where benign myoepithelial cells from a pleomorphic adenoma surround malignant epithelial cells. EGF was supplemented in various doses and the effects were evaluated following four days of cell culture. ELISA was performed to determine MMP-2 secretion levels. Gene expression for E-cadherin and $\beta$-catenin was analyzed using quantitative polymerase chain reaction. The results revealed that E-cadherin expression decreased when the cells were supplemented with $5 \mathrm{ng} / \mathrm{ml}$ EGF. ELISA results indicated that MMP-2 secretion increased when EGF was supplemented at concentrations of 5 and $10 \mathrm{ng} / \mathrm{ml}$. The present findings demonstrated that EGF may be involved in the epithelial-mesenchymal transition process via altering the E-cadherin/ $\beta$-catenin complex and increasing MMP-2 secretion, which may then favor the dissolution of the basement membrane to the benefit of malignant cell clusters, contributing to the development of an invasive phenotype in this in vitro model of tumorigenesis.
\end{abstract}

\section{Introduction}

Tumor progression is a complex phenomenon that involves the interaction between tumor cells and the surrounding

Correspondence to: Miss Natalia Festugatto Navarini, Department of Oral Pathology, São Leopoldo Mandic Institute and Research Center, 13 José Rocha Junqueira Street, Campinas, São Paulo 13045-755, Brazil

E-mail: natalianavarini@hotmail.com

Key words: E-cadherin, $\beta$-catenin, matrix metalloproteinase-2, myoepithelial cell, epithelial growth factor, tumor microenvironment tissues, promoting a plastic phenotype referred to as the epithelial-mesenchymal transition (EMT) (1). This process involves alterations in cell-cell and cell-matrix interactions, and consequently the acquisition of a motile phenotype $(1,2)$. The molecules involved in cell-cell interactions assume a significant role in physiological events and pathological conditions such as inflammatory and neoplastic processes (2). Among such molecules, calcium-dependent transmembrane glycoproteins (epithelial-cadherin) expressed in epithelial tissues, termed E-cadherins, are highlighted (3).

E-cadherin is associated with a group of intracellular proteins termed catenins, which bind to the actin filaments of the cytoskeleton (3). Cadherins and catenins form a single functional complex so that the deletion or mutation of one of these proteins may result in a loss of function or the disruption of cell-cell adhesion (4). Studies have revealed that the $\mathrm{E}$-cadherin/ $\beta$-catenin complex $(\mathrm{E} \beta \mathrm{C})$ is a key regulatory factor required for the maintenance of normal intercellular adhesion in carcinomas, acting as an invasion suppressor molecule $(1,2,5)$. Consequently, a loss of $\mathrm{E} \beta \mathrm{C}$ function allows or increases the risk of neoplastic invasion of the underlying normal tissue (5). Changes to E-cadherin expression patterns may, therefore, be a vital step in the development and progression of malignant tumors $(5,6)$.

During the early stages of glandular tumors in situ, malignant luminal cells are surrounded by an intact layer of myoepithelial cells (7). However, this condition is short-lived, as myoepithelial cells rapidly disappear $(8,9)$. A number of hydrolytic enzymes, released either by the tumor cells or by cells surrounding the tumor, combined with certain growth factors may favor disruption of the basement membrane, contributing to EMT (10). Matrix metalloproteinases (MMPs) act by degrading almost all components of the basement membrane and the extracellular matrix (ECM) (11). In malignant disease, metastasis-associated MMP overexpression has been reported to be associated with cytokines such as epidermal growth factor (EGF), which in turn may serve a role in modulating a developing metastatic potential in neoplastic cells (12).

EGF has been extensively investigated in invasive tumor phenotypes, and several in vitro studies have 
demonstrated the proliferative effect of EGF on a variety of cell types $(4,13,14)$. Additionally, EGF performs an essential role in promoting a migratory phenotype, even in benign cells $(4,14)$. When EGF binds to its receptor, E-cadherin is internalized from the cell membrane, reducing cell-cell contact, which in turn weakens the epithelial layer and induces EMT $(15,16)$. EGF has been revealed to upregulate a number of MMPs in squamous cell carcinoma cells, as well as in myoepithelial cells (15).

Considering the importance of myoepithelial cells to the invasive behavior of cancer cells in salivary gland neoplasms $(17,18)$, the present study aimed to evaluate the role of EGF on E-cadherin/ $\beta$-catenin gene expression and MMP-2 secretion in an in vitro model of tumorigenesis, which mimics a situation where in situ neoplastic cells of oral carcinoma are surrounded by benign myoepithelial cells (19).

\section{Materials and methods}

Cell culture. The present study was approved by the Research Ethics Committee of the São Leopoldo Mandic Dental Institute and Research Center (Campinas, Brazil; approval no. 1.468.890/2016). Benign myoepithelial cells were obtained from explants of excised salivary gland pleomorphic adenoma (PA), as previously described (18).

Cells were cultured in Dulbecco's modified Eagle's medium (DMEM; Sigma-Aldrich; Merck KGaA, Darmstadt, Germany) supplemented with $1 \%$ antimycotic-antibiotic solution (10,000 U/ml penicillin, $10 \mathrm{mg} / \mathrm{ml}$ streptomycin and $25 \mathrm{mg} / \mathrm{ml}$ amphotericin B in $0.9 \%$ sodium chloride; Sigma-Aldrich; Merck KGaA) containing 10\% donor calf serum (Gibco; Thermo Fisher Scientific, Inc., Waltham, MA, USA). Cells were then seeded onto $60-\mathrm{mm}$ diameter plastic culture dishes (110 cells $/ \mathrm{mm}^{2}$ ) and incubated under standard cell culture conditions $\left(37^{\circ} \mathrm{C}, 100 \%\right.$ humidity, $95 \%$ air and $\left.5 \% \mathrm{CO}_{2}\right)$. Once $100 \%$ confluence was reached, the cells were detached using $0.05 \%$ trypsin and subcultured at a density of 110 cells $/ \mathrm{mm}^{2}$ in $20 \mu \mathrm{g} / \mathrm{ml}$ fibronectin substratum (Sigma-Aldrich; Merck $\mathrm{KGaA}$ ). The cells were then seeded either onto polystyrene plates or 13-mm coverslips for subsequent experiments. The benign myoepithelial cells from PA seeded either on the polystyrene plates or coverslips were cultured in DMEM for $24 \mathrm{~h}\left(37^{\circ} \mathrm{C}, 100 \%\right.$ humidity, $95 \%$ air and $\left.5 \% \mathrm{CO}_{2}\right)$ prior to supplementation with malignant conditioned medium, which contains floating vital malignant cells that have lost their ability to adhere to polystyrene, and according to the method described by Martinez et al $(18,19)$, is likely to contain malignant stem cells.

For cell induction using malignant conditioned medium in vitro, CAL27 squamous cell carcinoma cells were obtained from the American Type Culture Collection (Manassas, VA, USA) and cultured as aforementioned. Cell culture medium (DMEM) was changed $48 \mathrm{~h}$ prior to use. Benign myoepithelial cells cultured in DMEM for $24 \mathrm{~h}$ were then incubated for four days with the unfiltered malignant conditioned medium $\left(37^{\circ} \mathrm{C}, 100 \%\right.$ humidity, $95 \%$ air and $\left.5 \% \mathrm{CO}_{2}\right)$, which contained non-adhered malignant epithelial cells. EGF was subsequently added at 5 or $10 \mathrm{ng} / \mathrm{ml}$ (BD Biosciences, San Jose, CA, USA). As a control group, myoepithelial cells were cultured in conventional non-conditioned DMEM.
Indirect immunofluorescence. Cells grown on coverslips were fixed in absolute methanol for $6 \mathrm{~min}$ at $-20^{\circ} \mathrm{C}$ and rinsed with PBS, followed by blocking with $1 \%$ bovine albumin (catalog no. A2058; Sigma-Aldrich; Merck KGaA) in PBS for $30 \mathrm{~min}$ at room temperature. Polyclonal rabbit E-cadherin (catalog no. H-108; dilution, 1:50; Santa Cruz Biotechnology, Inc., Dallas, TX, USA) and monoclonal mouse $\beta$-catenin (catalog no. 610154; dilution, 1:50; BD Biosciences) primary antibodies were incubated for $1 \mathrm{~h}$ at room temperature. Control staining was performed using PBS in place of the primary antibody. The secondary antibody used was either biotinylated goat anti-rabbit (catalog no. 4050-08; dilution) or goat anti-mouse IgG (catalog no. 1031-08; dilution, 1:150) (both from Vector Laboratories, Inc., Burlingame, CA, USA), which were incubated for $30 \mathrm{~min}$ at room temperature. Fluorescein-streptavidin conjugate (catalog no. SA-5001; dilution, 1:150; Vector Laboratories, Inc.) was used for the second step. The preparations were rinsed and mounted using DAPI-associated Vectashield ${ }^{\circledR}$ (catalog no. H-1200; Vector Laboratories, Inc.) and the slides were maintained at $4^{\circ} \mathrm{C}$ for up to $24 \mathrm{~h}$ to prevent loss of fluorescence. The images were assessed immediately after staining using a Zeiss Axioskop 2 conventional fluorescence microscope (original magnification, x400; Carl Zeiss MicroImaging GmbH, Jena, Germany) equipped with 63X Plan Apochromatic 1.4NA and 100X Plan Apochromatic 1.4NA objectives (Carl Zeiss MicroImaging $\mathrm{GmbH}$ ).

Reverse transcription-quantitative polymerase chain reaction $(R T-q P C R)$. Total RNA was isolated from the cells cultured under differing conditions using TRIzol ${ }^{\circledR}$ reagent (Molecular Research Center, Cincinnati, OH, USA). The RNA samples were treated with DNase (1:1, DNase I, RNase-free kit; catalog no. EN0521; Fermentas; Thermo Fisher Scientific, Inc.). Reverse transcription was performed using the Superscript III First-Strand cDNA Synthesis kit (Invitrogen; Thermo Fisher Scientific, Inc.), according to the manufacturer's protocol. The primer sets were as follows: $\beta$-catenin forward, 5'-GCA GTTCGCCTTCACTATGGA-3' and reverse, 5'-GACAAA GGGCAAGATTTCGAATC-3'; E-cadherin forward, 5'-TCA TGAGTGTCCCCCGGTAT-3' and reverse, 5'-TCAAACACG AGCAGAGAATCATAAG-3'; GAPDH (used as the internal reference gene) forward, 5'-TGGCAAAGTGGAGATTGT TGCC-3' and reverse, 5'-AAGATGGTGATGGGCTTC CCG-3'. RT-qPCR was performed using a 7500 Real-Time PCR system (Applied Biosystems; Thermo Fisher Scientific, Inc.) with SYBR-Green/ROX (Maxima; Fermentas; Thermo Fisher Scientific, Inc.), as the detection dye. Cycling conditions were as follows: $10 \mathrm{~min}$ at $95^{\circ} \mathrm{C}$ followed by 40 cycles of $95^{\circ} \mathrm{C}$ for $15 \mathrm{sec}$ and $60^{\circ} \mathrm{C}$ for $1 \mathrm{~min}$. Quantification of the data was performed using the 7500 software (7500 Fast Red Time PCR systems v2.0.6; Applied Biosystems; Thermo Fisher Scientific, Inc.) and the relative expression levels were calculated according to the comparative $\mathrm{Cq}$ method, as $2^{-\Delta \Delta \mathrm{Cq}}(20)$. Each qPCR experiment was repeated three times.

ELISA. MMP-2 quantification was performed using the human MMP-2 ELISA kit (catalog no. DY902; R\&D Systems, Inc., Minneapolis, MN, USA). Coating containing the capture antibody and blocking were provided in the kit and performed according to the manufacturer's protocol. 
The reactions were performed on a 96-well plate (catalog no. 80040LE 0903; Apogent Technologies, Inc., Milwaukee, MI, USA), according to the manufacturer's recommendations. Supernatant obtained from the cell cultures were harvested and centrifuged at $5,000 \times \mathrm{g}$ at $4^{\circ} \mathrm{C}$ for $15 \mathrm{~min}$, $100 \mu 1$. The wells were then rinsed three times with washing buffer $(0.05 \%$ Tween-20 in PBS, $\mathrm{pH}$ 7.2) prior to adding the standard (provided in the kit) and supernatant in duplicate wells. Following incubation for $2 \mathrm{~h}$ at room temperature, the plates were washed again and incubated with $100 \mu \mathrm{l}$ of the detection antibody at room temperature for $2 \mathrm{~h}$. The plates were then rinsed three times $(0.05 \%$ Tween-20 in PBS, pH 7.2), treated with $100 \mu \mathrm{l}$ of streptavidin-horseradish peroxidase for $20 \mathrm{~min}$ at room temperature and rinsed three times with washing buffer (0.05\% Tween-20 in PBS, pH 7.2). Substrate solution (100 $\mu \mathrm{l}$; provided in the kit) was added to each well and incubated for $15 \mathrm{~min}$ in the dark at room temperature. The reaction was stopped by adding $50 \mu \mathrm{l}$ stop solution (provided in the kit), and the color was measured at $450 \mathrm{~nm}$, using an automated microplate spectrophotometer (Epoch), associated with the software GenS (v1.10.8) (both from BioTek Instruments, Inc., Winooski, VT, USA). Total MMP was quantified in $\mathrm{ng} / \mathrm{ml}$. Results were calculated using the standard curves created in each assay. The ELISA assays were performed in a blind manner and in triplicate.

Statistical analysis. Data are expressed as the mean \pm standard deviation. In order to compare the results between distinct conditions, one-way analysis of variance was used with Tukey's post hoc test. $\mathrm{P}<0.05$ was considered to indicate a statistically significant difference. All statistical calculations were performed with GraphPad Prism v 6.0 software (GraphPad Software, Inc., La Jolla, CA, USA).

\section{Results}

Indirect immunofluorescence of E-cadherin and $\beta$-catenin. Indirect immunofluorescence to E-cadherin and $\beta$-catenin in the co-cultured cells under different conditions is illustrated in Fig. 1. E-cadherin and $\beta$-catenin were observed to be immunoexpressed in the cytoplasm of the malignant cells under all studied conditions. No immunostaining was observed in the myoepithelial cells, even following EGF supplementation.

$m R N A$ E-cadherin and $\beta$-catenin expression. In order to quantify the results observed using immunofluorescence, the expression of E-cadherin and $\beta$-catenin was assessed using qPCR (Fig. 2) following EGF supplementation. E-cadherin expression was significantly downregulated in the cells treated with $5 \mathrm{ng} / \mathrm{ml}$ EGF, when compared with the control group $(\mathrm{P}<0.05$; Fig. $2 \mathrm{~A})$, which was statistically similar to the group treated with $10 \mathrm{ng} / \mathrm{ml}$ EGF $(\mathrm{P}>0.05)$. No difference was observed in $\beta$-catenin mRNA expression levels following EGF supplementation (Fig. 2B), as compared with the control $(\mathrm{P}>0.05)$.

MMP-2 protein secretion. MMP-2 levels in the co-cultured cells under different conditions are presented in Fig. 3. The results indicated an increase in MMP-2 secretion in the cells

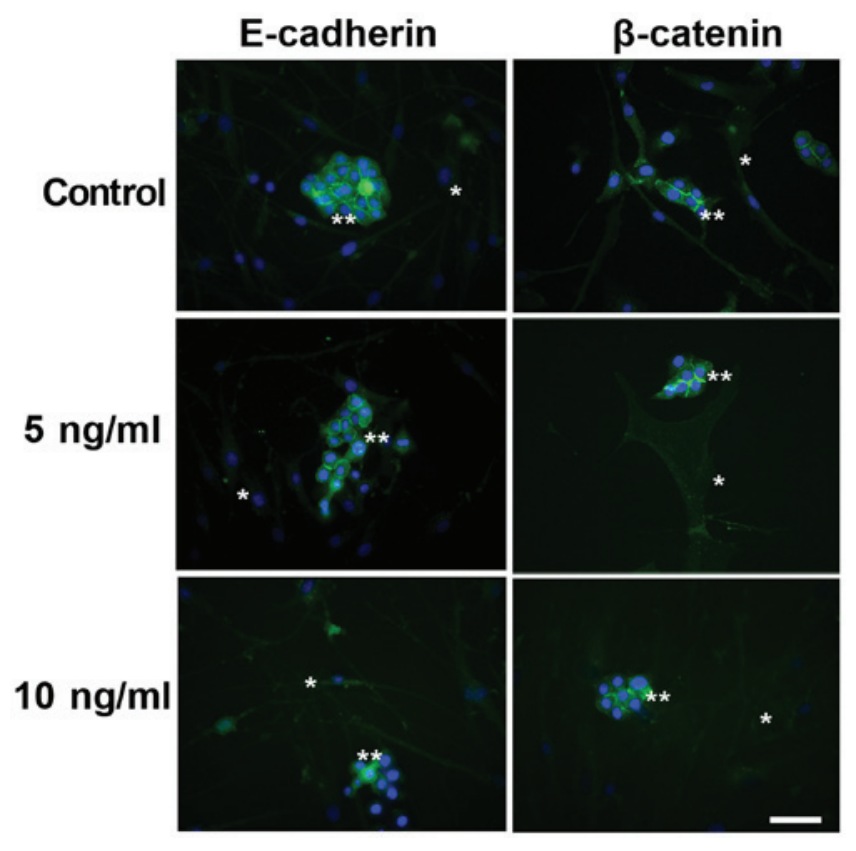

Figure 1. Immunostaining for E-cadherin and $\beta$-catenin in myoepithelial cells $\left(^{*}\right)$ and in malignant cells $\left(^{* *}\right)$ after four days of cell culture without EGF (control) or with 5 and $10 \mathrm{ng} / \mathrm{ml}$ EGF. E-cadherin and $\beta$-catenin were immunoexpressed in the cytoplasm of malignant cells under all studied conditions. No immunostaining was observed in the myoepithelial cells. Nuclei stained with DAPI appear in blue. Scale bar, $50 \mu \mathrm{m}$. EGF, epidermal growth factor.

following supplementation with 5 and $10 \mathrm{ng} / \mathrm{ml}$ EGF, when compared with the control group $(\mathrm{P}<0.05)$.

\section{Discussion}

Metastasis is a process that involves several sequential and interrelated steps, including detachment, migration, invasion and adhesion, and in this context, the tumor microenvironment has been widely studied and is considered an important factor in the so named 'invasion-metastasis cascade' $(21,22)$. Growth factors are secreted by normal and cancerous cells within the tumor microenvironment, and are involved in tumor initiation and progression (4). EGF has been revealed to be associated with cell proliferation and migration in contexts such as salivary gland tumors (17) and EMT (15).

EMT is a result of paracrine signaling by stromal-derived factors, and is also a potential source of cells within the stromal compartment; cross-talk between neoplastic and stromal cells may affect the production and secretion of a number of molecules and matrix proteases, including the E-cadherin/ $\beta$-catenin complex, which is responsible for maintaining adhesive properties, and MMPs, which have previously been implicated in degrading components of the basement membrane (10).

In the present in vitro study, MMP-2 secretion and E-cadherin/ $\beta$-catenin expression were analyzed following four days of cell culture, wherein myoepithelial cells, mimicking an in situ condition, surrounded carcinoma cells. As co-culture time progresses, benign cells begin to disappear until only malignant cells are left (8), and such interactions between neoplastic cells and the stroma can no longer be detected. This behavior is associated with basement membrane disruption through the action of MMPs, which culminates in EMT-associated invasion (15). 
A

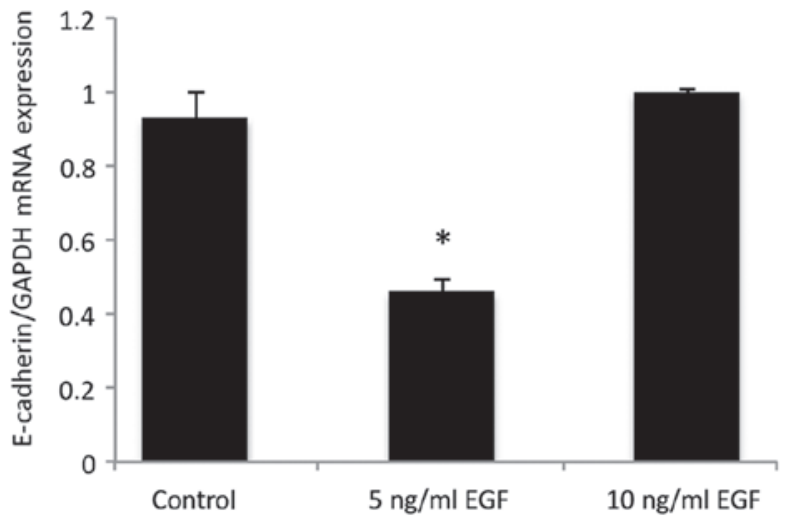

B

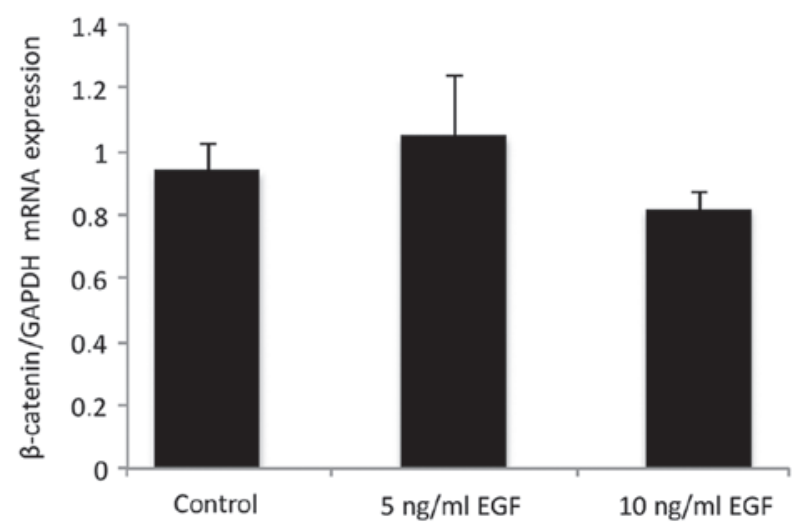

Figure 2. Quantitative polymerase chain reaction analysis of (A) E-cadherin and (B) $\beta$-catenin transcript levels without (control) and with 5 and $10 \mathrm{ng} / \mathrm{ml}$ EGF. GAPDH was used as the internal reference gene. The data are representative of three independent experiments conducted in duplicate (mean \pm standard deviation). "P<0.05, compared with the control group. EGF, epidermal growth factor.

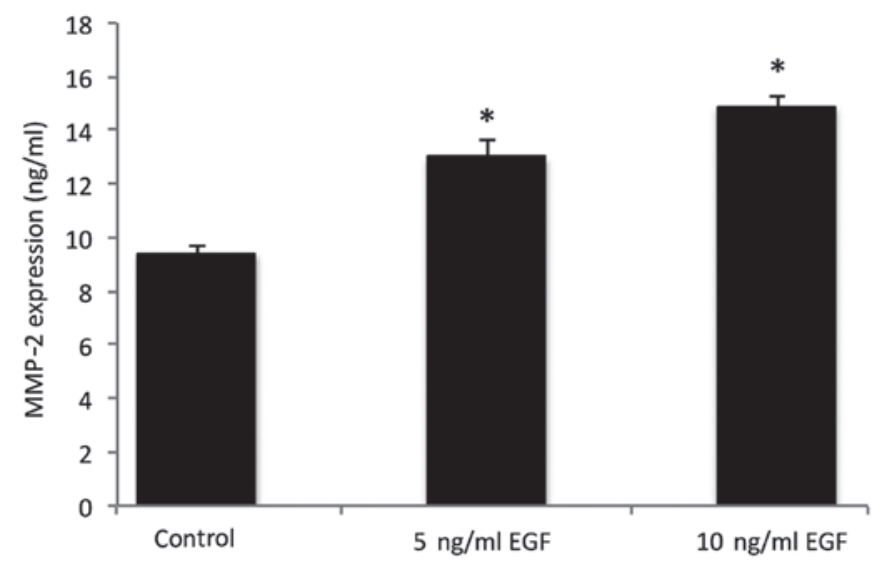

Figure 3. MMP-2 expression levels without EGF (control) or with 5 and $10 \mathrm{ng} / \mathrm{ml}$ EGF. The values are representative of three independent experiments conducted in duplicate (mean \pm standard deviation). ${ }^{*} \mathrm{P}<0.05$, compared with the control group. MMP-2, matrix metalloproteinase-2; EGF, epidermal growth factor.

Such findings corroborate an invasive behavior by the malignant cells, which occurs in the presence of EGF downregulating E-cadherin expression and increasing MMP-2 secretion.

In epithelial cells, EGF has been associated with increasing MMP secretion, contributing to a metastatic phenotype by modifying certain ECM components and promoting a motile behavior, which is typical of EMT (12). In addition, MMP-2 is known to promote modifications to cell morphology and phenotype in vitro (13), which can directly affect cell adhesion (11). Furthermore, MMP-2, which is one of the major enzymes involved in degrading collagen types I and IV as well as the ECM, is overexpressed in highly metastatic tumors, demonstrating the importance of this molecule in cancer invasion and metastasis (23).

E-cadherin expression is impaired in a number of tumor types, and its loss from the cell surface due to genetic or epigenetic events leads to disruption of cell contacts, tumor cell detachment, shape change and local invasion, all of which are events known to initiate EMT (24). In this setting, $\beta$-catenin is considered as one of the most important factors involved in decreasing cell-cell interactions in malignant epithelial cells (25). In an environment of degradation and destabilization of cell-cell adhesion and decreased E-cadherin expression, $\beta$-catenin is released into the cytoplasm causing it to accumulate and eventually lead to nuclear translocation (25). Cadherin switching is a hallmark of EMT, where E-cadherin can be replaced by an abnormal expression of $\mathrm{N}$-cadherin without changes in E-cadherin levels (26). This event may be affected by cytokines and growth factors (27). It has previously been reported that EGF is also involved in regulating cell adhesion in several solid malignancies (28), and that EGF stimulation causes E-cadherin relocation from the membrane to the perinuclear area during EMT in head and neck squamous cell carcinoma (29).

Dynamic evaluation of certain factors, such as EGF, with regard to E-cadherin/ $\beta$-catenin expression may yield data concerning key biological processes in tumorigenesis in vitro. However, the use of E-cadherin/ $\beta$-catenin as prognostic markers in salivary gland tumors containing myoepithelial cells, for instance, may not necessarily generate definitive predictive values (30). Furuse et al (30) demonstrated that such molecules may be immunoexpressed in normal salivary glands as well as in malignant neoplastic tissues, be it invasive or non-invasive. In such cross-sectional studies, biological timing is difficult to predict histologically. Additionally, although a quantitative difference may exist between the physiological and neoplastic expression of E-cadherin/ $\beta$-catenin, as demonstrated in the present in vitro study, such differences are likely to go undetected using qualitative methods.

In conclusion, the present study demonstrated that EGF performs an important role in the EMT process by altering the expression of the E-cadherin/ $\beta$-catenin complex and increasing MMP-2 secretion. This could, in turn, favor the dissolution of the basement membrane, aiding the maintenance of malignant cell clusters in detriment of stromal cells and encouraging an invasive phenotype, based on this in vitro model of tumorigenesis.

\section{Acknowledgements}

The authors wish to thank Ms Pollyanna Tombini Montaldi (Department of Oral Pathology, Immunology and Molecular 
Biology, São Leopoldo Mandic Institute and Research Center) and Mrs Vanessa Araújo (Department of Oral Pathology, Immunology and Molecular Biology, São Leopoldo Mandic Institute and Research Center) for their excellent technical expertise and assistance and the Brazilian Council for Scientific and Technological Development (grant no. 471153/2013-3).

\section{References}

1. Thiery JP and Sleeman JP: Complex networks orchestrate epithelial-mesenchymal transitions. Nat Rev Mol Cell Biol 7: 131-142, 2006.

2. Khew-Goodall Y and Wadham C: A perspective on regulation of cell-cell adhesion and epithelial-mesenchymal transition: Known and novel. Cells Tissues Organs 179: 81-86, 2005.

3. Stappert J and Kemler R: The cadherin superfamily. Adv Mol Cell Biol 28: 27-63, 1999.

4. Lu Z, Ghosh S, Wang Z and Hunter T: Downregulation of caveolin-1 function by EGF leads to the loss of E-cadherin, increased transcriptional activity of beta-catenin, and enhanced tumor cell invasion. Cancer Cell 4: 499-515, 2003.

5. Wijnhoven BP, Dinjens WN and Pignatelli M: E-cadherin-catenin cell-cell adhesion complex and human cancer. Br J Surg 87: 992-1005, 2000.

6. Pećina-Slaus N: Tumor supressor gene E-cadherin and its role in normal and malignant cells. Cancer Cell Int 3: 17, 2003.

7. Altemani A, Martins MT, Freitas L, Soares F, Araújo NS and Araújo VC: Carcinoma ex pleomorphic adenoma (CXPA): Immunoprofile of the cells involved in carcinomatous progression. Histopathology 46: 635-641, 2005.

8. Martinez EF, de Araújo NS and de Araújo VC: How do benign myoepithelial cells from in situ areas of carcinoma ex-pleomorphic adenoma favor tumor progression? J Cell Commun Signal 9: 279-280, 2015

9. Silva CA, Martinez EF, Demasi AP, Altemani A, da Silveira Bossonaro JP, Araújo NS and de Araújo VC: Cellular senescence and autophagy of myoepithelial cells are involved in the progression of in situ areas of carcinoma ex-pleomorphic adenoma to invasive carcinoma. An in vitro model. J Cell Commun Signal 9: 255-265, 2015.

10. Smith BN and Bhowmick NA: Role of EMT in metastasis and therapy resistance. J Clin Med 5: pii: E17, 2016.

11. Gialeli C, Theocharis AD and Karamanos NK: Roles of matrix metalloproteinases in cancer progression and their pharmacological targeting. FEBS J 278: 16-27, 2011.

12. Wilkins-Port CE and Higgins PJ: Regulation of extracellular matrix remodeling following transforming growth factor-beta1/epidermal growth factor-stimulated epithelial-mesenchymal transition in human premalignant keratinocytes. Cells Tissues Organs 185: 116-122, 2007.

13. Antoniades HN and Owen AJ: Growth factors and regulation of cell growth. Annu Rev Med 33: 445-463, 1982.

14. Navarini NF, Araújo VC, Brown AL, Passador-Santos F, Souza IF, Napimoga MH, Araújo NS and Martinez EF: The EGF signaling pathway influences cell migration and the secretion of metalloproteinases by myoepithelial cells in pleomorphic adenoma. Tumour Biol 36: 205-211, 2015.
15. Ahmed S and Nawshad A: Complexity in interpretation of embryonic epithelial-mesenchymal transition in response to transforming growth factor-beta signaling. Cells Tissues Organs 185: 131-145, 2007.

16. Gonzalez DM and Medici D: Signaling mechanisms of the epithelial-mesenchymal transition. Sci Signal 7: re8, 2014.

17. Barsky SH and Karlin NJ: Mechanisms of disease: Breast tumor pathogenesis and the role of the myoepithelial cell. Nat Clin Pract Oncol 3: 138-151, 2006.

18. Martinez EF, Demasi AP, Napimoga MH, Arana-Chavez VE, Altemani A, de Araújo NS and de Araújo VC: In vitro influence of the extracellular matrix in myoepithelial cells stimulated by malignant conditioned medium. Oral Oncol 48: 102-109, 2012.

19. Martinez EF, Montaldi PT, de Araújo NS, Altemani A and de Araújo VC: A proposal of an in vitro model which mimics in situ areas of carcinoma. J Cell Commun Signal 6: 107-109, 2012.

20. Livak KJ and Schmittgen TD: Analysis of relative gene expression data using real-time quantitative PCR and the 2(-Delta Delta C(T)) method. Methods 25: 402-408, 2001.

21. McSherry EA, Donatello S, Hopkins AM and McDonnell S: Molecular basis of invasion in breast cancer. Cell Mol Life Sci 64: 3201-3218, 2007

22. Guan X: Cancer metastases: Challenges and opportunities. Acta Pharm Sin B 5: 402-418, 2015.

23. Cho WJ, Chow AK, Schulz R and Daniel EE: Matrix metalloproteinase-2, caveolins, focal adhesion kinase and c-Kit in cells of the mouse myocardium. J Cell Mol Med 11: 1069-1086, 2007.

24. Brooks SA, Lomax-Browne HJ, Carter TM, Kinch CE and Hall DM: Molecular interactions in cancer cell metastasis. Acta Histochem 112: 3-25, 2010.

25. Umbreit C, Flanjak J, Weiss C, Erben P, Aderhold C, Faber A, Stern-Straeter J, Hoermann K and Schultz JD: Incomplete epithelial-mesenchymal transition in p16-positive squamous cell carcinoma cells correlates with $\beta$-catenin expression. Anticancer Res 34: 7061-7069, 2014.

26. Bryan RT: Cell adhesion and urothelial bladder cancer: The role of cadherin switching and related phenomena. Philos Trans R Soc Lond B Biol Sci 370: 20140042, 2015.

27. Wheelock MJ, Shintani Y, Maeda M, Fukumoto Y and Johnson KR: Cadherin switching. J Cell Sci 121: 727-735, 2008.

28. Smith A, Teknos TN and Pan Q: Epithelial to mesenchymal transition in head and neck squamous cell carcinoma. Oral Oncol 49: 287-292, 2013.

29. Holz C, Niehr F, Boyko M, Hristozova T, Distel L, Budach V and Tinhofer I: Epithelial-mesenchymal-transition induced by EGFR activation interferes with cell migration and response to irradiation and cetuximab in head and neck cancer cells. Radiother Oncol 101: 158-164, 2011.

30. Furuse C, Cury PR, Altemani A, dos Santos Pinto D Jr, de Araújo NS and de Araújo VC: Beta-catenin and E-cadherin expression in salivary gland tumors. Int J Surg Pathol 14: 212-217, 2006. 